\title{
MOLECULAR PHYLOGENY OF COMMON SUN SKINK, EUTROPIS MULTIFASCIATA (SQUAMATA: SCINCIDAE), OF NORTHWESTERN PART OF BANGLADESH
}

\author{
Mosharrof Hossain* and Che Jing \\ State Key Laboratory of Genetic Resources and Evolution, Kunming Institute of \\ Zoology, Chinese Academy of Sciences, Kunming 650223, China
}

\begin{abstract}
A study on the phylogenetic relationship of Bangladeshi Skink confirmed species as Eutropis multifasciata by Bayesian inference (BI) (100\%) and 98\% node support to maximum likelihood (ML) tree topology, respectively. The sequence divergences between Eutropis multifasciata and other congeneric species were significant, ranging from 0.1 to $13.6 \%$ for $16 S$ rRNA. Intraspecific genetic divergence within E. multifasciata was estimated $10.3 \%$. E. multifasciata formed a distinct clade with high posterior probability support. This maiden study on Bangladeshi Skink results support that one monophyletic subgroup containing all specimens of $E$. multifasciata and all recently recognized $E$. multifasciata populations have evolved from one common ancestor.
\end{abstract}

Key words: Scincidae, Eutropis multifasciata, phylogeny, 16S rRNA gene

\section{INTRODUCTION}

The genus Eutropis representing Asian radiation of Scincid lizards have 31 described species (Mausfeld et al. 2002) and many yet to undescribed species occurring from South Asian countries. The phylogenetic relationships of Asian Eutropis are far from being understood and therefore remain largely unclear and speculative. However, some major works provide quite comprehensive data on the Eutropis taxa recognized. Many more additional species have been described by researchers (Boulenger 1887, Rooij 1915, Smith 1935, Tikader and Sharma 1992, Mahony and Reza 2008). We have collected two specimens of robust form of Eutropis that closely resemble Eutropis $\left(25.636574^{\circ} \mathrm{N}, 88.636322^{\circ} \mathrm{E}\right)$. Because of limited size of sample and mutifasciata one from Lalpur $\left(24.1833^{\circ} \mathrm{N}\right.$, $88.9750^{\circ} \mathrm{E}$ ) and one from Dinajpur observational differences between specimens from India and those from South Asia, we report these specimens as Eutropis multifasciata pending a more thorough morphological and genetic analysis. Both the specimens were collected during the day while foraging in grassy vegetation.

*Author for correspondence: <mshzool@yahoo.com>. Department of Zoology, University of Rajshahi, Rajshahi-6205, Bangladesh

(c) 2018 Zoological Society of Bangladesh DOI: https://doi.org/10.3329/bjz.v47i1.42017 
Although, it is well documented from north-east India (Smith 1935, Das 1996, Sharma 2002, Das 2008), there is no substantial data on E. multifasciata in Bangladesh. Even Bangladesh has no scientifically maintained natural history museum or other recognized national repository for biological specimens, further adding difficulty when trying to confirm the presence or absence of presumed extant species. According to IUCN (2015) in Bangladesh have 13 species of skinks, and only four under genus Eutropis (i.e. E. carinata, E. dissimilis, E. multifasciata, E. macularia) that are described morphologically, or photograph compared elsewhere. However, it raises some contradiction of species description, distribution, and even systematic position. Most recently Khan (2007) described two new country records of skinks found in Chittagong, namely Scincella reevesi and Sphenomorpha indicus. The record (and photograph) of Scincella reevesi and Sphenomorpha indicus, based on photographs and general descriptions. Although both Scincella reevesi and Sphenomorphus indicus are likely to be present in Bangladesh, none of the above species have molecular or genetic databases in Bangladesh. Therefore, the present study has undertaken a step morphologically similar species of Eutropis multifasciata to confirm its genus and species by mitochondrial DNA analysis first time in this study.

\section{MATERIAL AND METHODS}

The specimens were collected from two localities, namely Lalpur $\left(24.1833^{\circ} \mathrm{N}\right.$, $\left.88.9750^{\circ} \mathrm{E}\right)$ and Dinajpur $\left(25.636574^{\circ} \mathrm{N}, 88.636322^{\circ} \mathrm{E}\right)$ in the north-western part of Bangladesh (Figs 1 and 4) between February and April, 2016 and stored in $95 \%$ ethanol. For the molecular analysis, small amount of livers/muscles were removed from anesthetized or dead specimens and stored at $-80^{\circ} \mathrm{C}$.

Ethical permission: Tissues of the studied specimens were carried to China for Research and study with the permission of Chief Conservator of Forest (Original permit/Certificate No.06/2017, BD 9118468, 30 March 2017) under the Forest Department and Ministry of Environment and Forest, Bangladesh. The voucher specimen's tissues were deposited in the Forest Department and ethical rules were followed Wildlife Preservation and Security Acts, 2012. Collected tissues from the specimens are not threatened species and not listed in IUCN Red list or CITES. All specimens' tissues were collected from nonprotected areas.

Morphological description: The following characteristics were followed for proper identification of the specimens as described by Boulenger (1887): (1) Snout moderate and obtuse, (2) lower eyelid scaly, (3) nostril behind vertical of the suture between rostral and first tibial, (4) ear opening roundish or oval, (5) 
dorsal scale more or less distinctly tri-carinate (nuchals and laterally keeled), (6) the hind limbs reaches the wrist and sub-digital lamellae smooth, (7) tail larger than body and tapering to the end, (8) body color brown to olive and ventral surface light yellowish and (9) limbs pentadactylies.

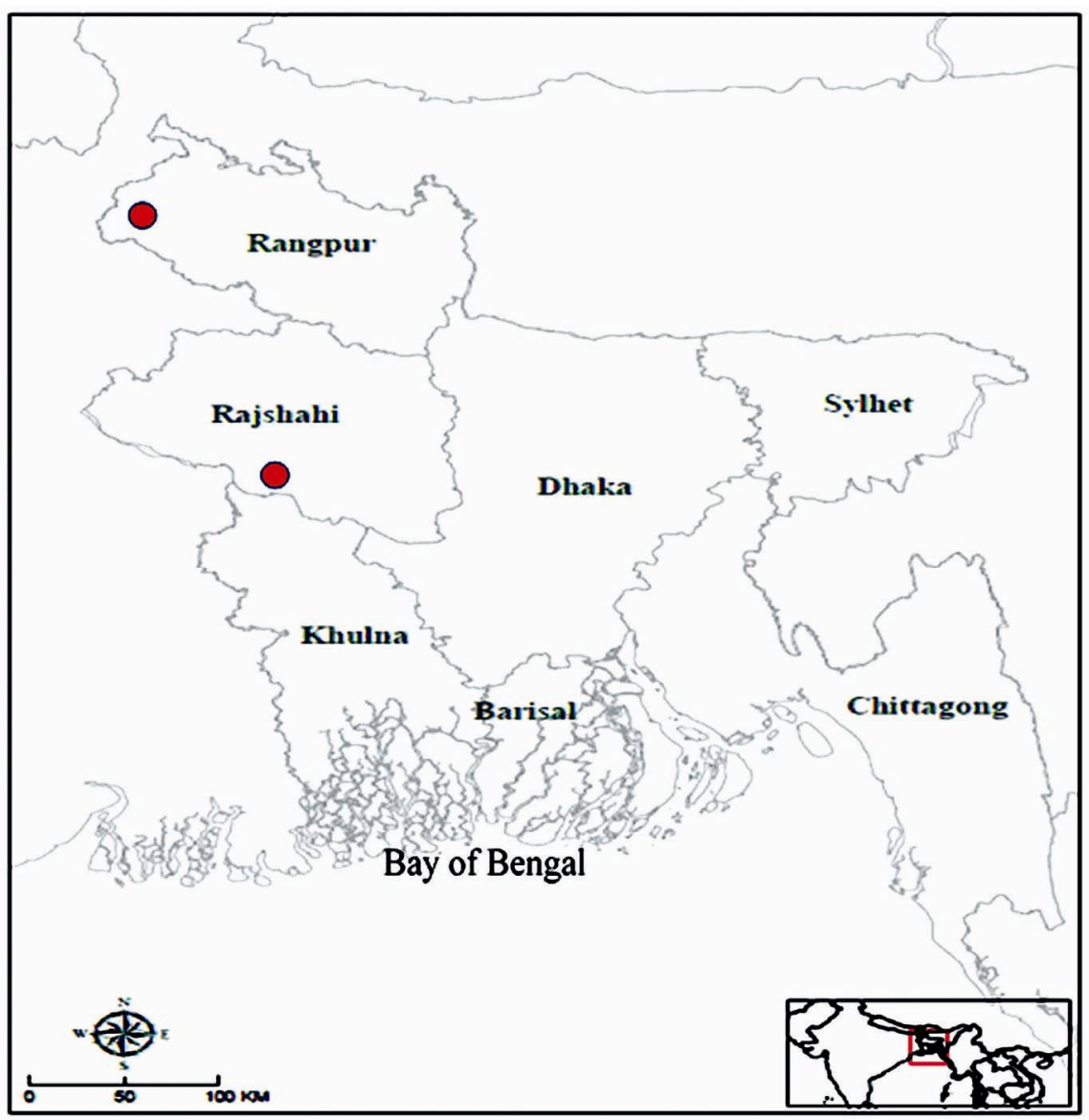

Fig. 1. Sites (color filled circle) of sampling specimens, northwestern part of Bangladesh.

DNA extraction and PCR protocol: Total genomic DNA was extracted from the muscle or liver tissues with three steps of standard phenol-chloroform methods of Sambrook et al. (1989) with some modifications. The tissues were homogenized in $0.6 \mathrm{ml}$ of STE buffer containing $10 \mathrm{mM}$ tris/ $\mathrm{HCl}(\mathrm{pH} 8.0), 0.10 \mathrm{ml}$ SDS (10\%) and added $0.30 \mathrm{ml}$ proteinase $\mathrm{K}(0.1 \mathrm{mg} / \mathrm{ml})$ for digesting protein for 4 - $12 \mathrm{hrs}$ at $56^{\circ} \mathrm{C}$. The solution was treated with phenol and chloroform /isoamyl alcohol, finally DNA was precipitated with ethanol. The DNA 
precipitates were dried and then resuspended in $0.5 \mathrm{ml}$ of $\mathrm{TE}(10 \mathrm{mM}$ Tris $/ \mathrm{HCl}$, $1 \mathrm{mM}$ EDTA, $\mathrm{pH}$ 8.0), and quantity was determined by measuring the absorbance at $260 \mathrm{~nm}$ and the concentration, purity and quality were determined by measuring the absorbance at 260/280 $\mathrm{nm}$ and 230/260 ratios using a NanoDrop TM 1000 spectrophotometer (NanoDrop Technologies Inc., Wilmington, DE, USA) and quality was checked by $1.2 \%$ agarose gel. Extracted DNA were appropriately labeled and stored at $-20^{\circ} \mathrm{C}$ for analysis, however $1.5 \mu \mathrm{l}$ of working DNA was used for polymerase chain reaction (PCR).

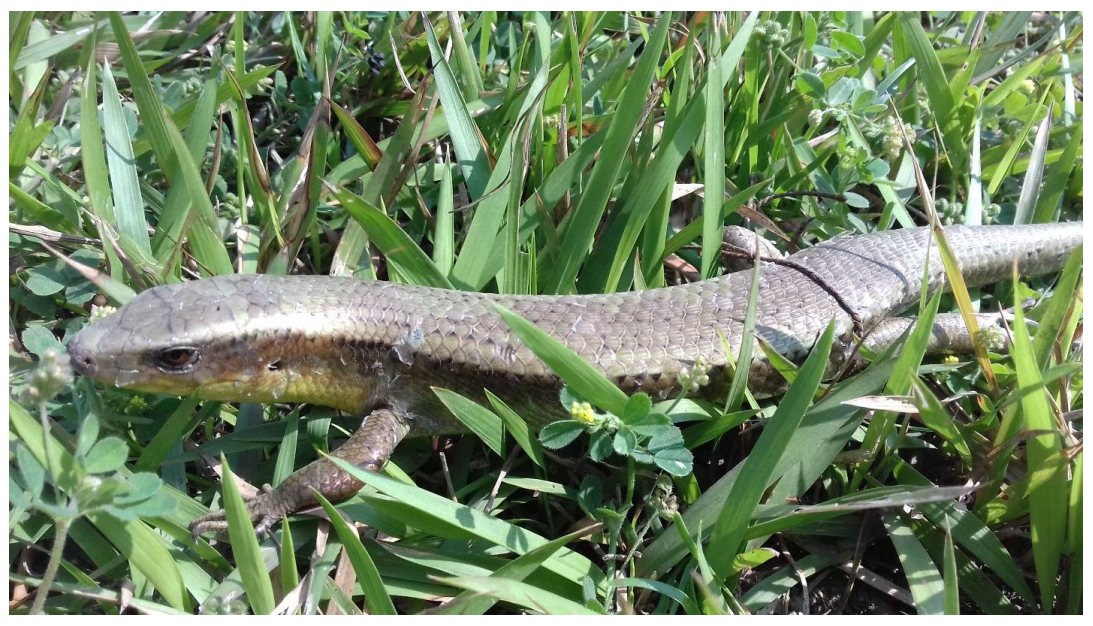

Fig. 1. Eutropis multifasciata in natural habitat found at Lalpure, Natore, Bangladesh.

One pair of primers (2215 and 2216) was used for the amplification of Eutropis DNA. The primer sequences as 2215 (16SAR 5' CGCCTGTTTAYCAAAAA CAT-3') forward and 2216 (16SBR 5'-CCGGTYTGAACTCAGATCAYGT-3') reverse designed according to Bossuyt and Milinkovitch (2000). The PCR mixture was prepared from the company in a final volume of $25 \mu \mathrm{l}$ containing PCR buffer 2.5 $\mu \mathrm{l}$, forward and reverse primer $1 \mu \mathrm{l}$ each, dNTPs $1 \mu \mathrm{l}$, Taq polymerase $0.25 \mu \mathrm{l}$ and remaining was sterile water. In PCR, the $16 \mathrm{~S}$ rRNA gene was amplified for 35 cycles, each consisting of denaturing at $94^{\circ} \mathrm{C}$ for $1 \mathrm{~min}$, annealing for $40 \mathrm{sec}$ at $55^{\circ} \mathrm{C}$ and extension for $1 \mathrm{~min}$ at $72^{\circ} \mathrm{C}$. The PCR product was checked in $2 \%$ agarose gel under UV immunofluorescence before sequencing.

Sequencing and phylogenetic analysis: The purified PCR products were directly sequenced with an $\mathrm{ABI}$ automated DNA sequencer in both the directions for each species DNA. Sequence data obtained for each sample were adjusted manually by eye using DNASTARv.7.1 (DNASTAR Inc., Madison, WI, USA). The sequences of each gene region were aligned using the ClustalW option of Bioedit (Hall 1999). They were submitted for BLAST search in GenBank to ensure the 
target sequences had been properly amplified. The obtained sequences were deposited in National Centre for Biotechnology Information (NCBI) for accession numbers (MK524576). Available sequences for these genus and species were downloaded from GenBank and an out group (Table 1).

Table 1. List of all specimens, locality and accession number used in this study

\begin{tabular}{|c|c|c|c|}
\hline Genus & Species & Locality & Accession No. \\
\hline Eutropis & multifasciata & Lalpur, Bangladesh & This study \\
\hline Eutropis & multifasciata & Dinajpur, Bangladesh & This study \\
\hline Eutropis & multifasciata & Philippines & JF497984 \\
\hline Eutropis & multifasciata & China & AY159083 \\
\hline Eutropis & multifasciata & Indonesia & AY 159082 \\
\hline Eutropis & multifasciata & Laos & DQ238897 \\
\hline Eutropis & multifasciata & Cambodia & AY 151459 \\
\hline Eutropis & multifasciata & Thailand & $\mathrm{AB} 028788$ \\
\hline Eutropis & multifasciata & Kaziranga, Assam, India & JQ767964 \\
\hline Eutropis & macularia & Satkosa, Orissa, India & JQ767961 \\
\hline Eutropis & macularia & Saravati valley, Karnataka, India & JQ767960 \\
\hline Eutropis & macularia & Bondla, Goa, India & JQ767959 \\
\hline Eutropis & macularia & Ponmudi, Kerala, India & JQ767958 \\
\hline Eutropis & macularia & Bagdogra, West Bengal, India & JQ767957 \\
\hline Eutropis & rufigera & Mt. Harriat, Andaman Is. $\square$ India & AY 159079 \\
\hline Eutropis & quadricarinata & Chattin, Myanmar & AY159089 \\
\hline Eutropis & macrophthalma & Java, Indonesia & AY159077 \\
\hline Eutropis & indreprensa & NW Panay, Philippined & AY159076 \\
\hline Eutropis & tytleri & Mt. Harriat, Andaman island, India & AY159074 \\
\hline Eutropis & beddomii & Deomali, Orissa, India & JQ767965 \\
\hline Eutropis & bibronii & Rushikulya, Orissa, India & JQ767963 \\
\hline Eutropis & clivicola & Parambikulam, Kerala, India & JQ767956 \\
\hline Eutropis & trivittata & Satara, Maharashtra, India & JQ767951 \\
\hline Eutropis & nagarjuni & Nagarjunasgor, Andra Pradesh, India & JQ767952 \\
\hline Eutropis & dissimilis & Myanmar & AY159075 \\
\hline Eutropis & macularia & Myanmar & AY159078 \\
\hline Eutropis & madaraszi & Sri Lanka & AY 159080 \\
\hline Eutropis & multicarinata & Luzon, Philippines & AY159081 \\
\hline Eutropis & cumingi & Luzon, Philippines & DQ238896 \\
\hline Eutropis & carinata & Kutch, Gujarat, India & JQ767955 \\
\hline Eutropis & carinata & Karnataka, India & JQ767953 \\
\hline Eutropis & macularia & Pakistan & AY070353 \\
\hline Eutropis & longicaudata & Phong Nha-Ke Bang, Vietnam & AY070359 \\
\hline Eutropis & rufigera & Nicobar, India & JQ767962 \\
\hline Scelotes & caffer & Brandberg, South Africa & AY217985 \\
\hline
\end{tabular}




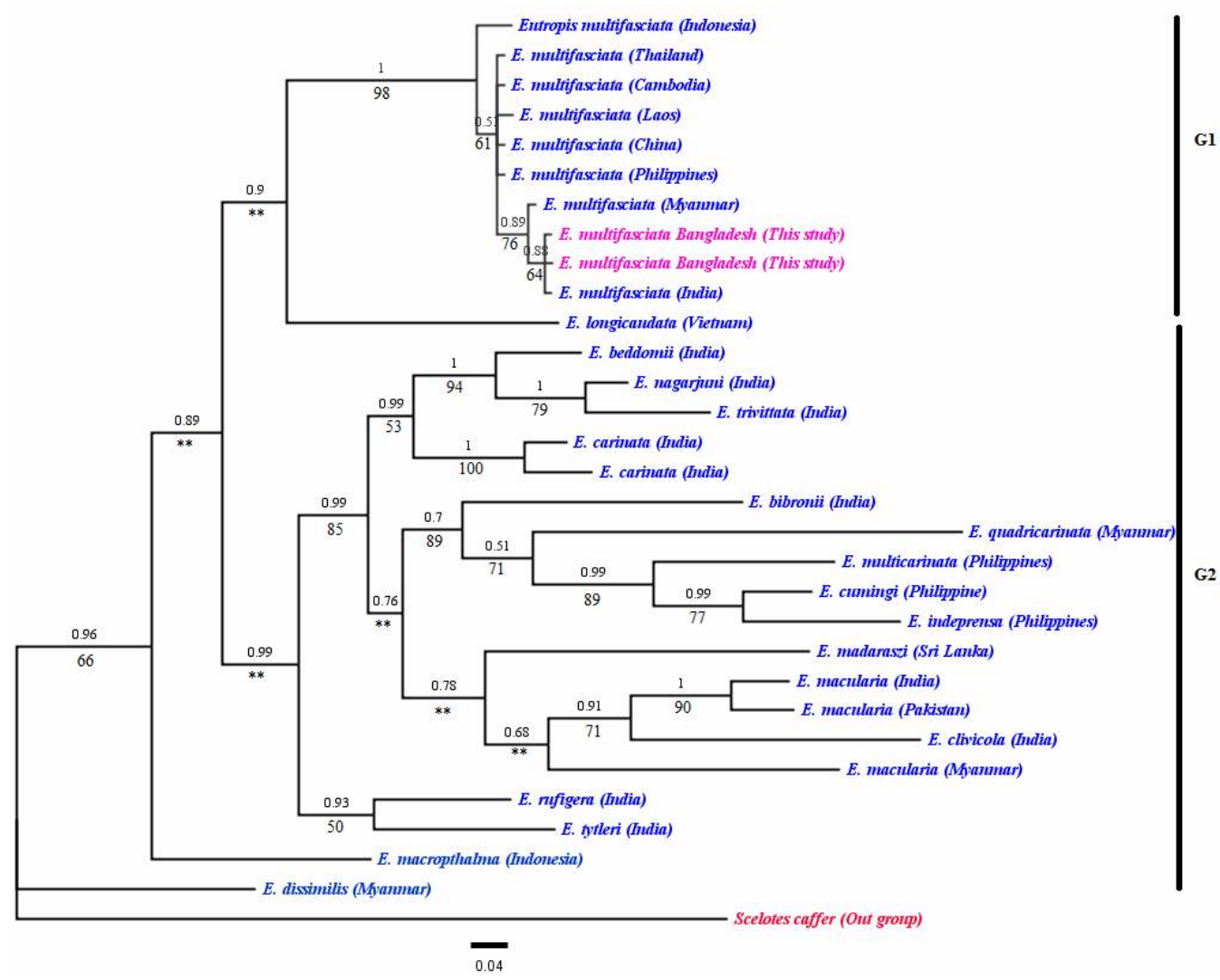

Fig. 2. Bayesian Inference (BI) tree based on mitochondrial DNA (16S rRNA gene) using the GTR+G+I substitution model from 30 Eutropis haplotypes with Scelotes caffer as an out group. The bootstrap values are given above the branches (BI) and below the branches (ML) are based on 1000 replication in both analyzed. The node support values $<50 \%$ are denoted by '**'for maximum likelihood. The scale bar represents 0.04 nucleotide substitution per site for this tree.

The nucleotide sequences of the $16 \mathrm{~S}$ gene were aligned with sequences for other Eutropis species available from GenBank with ClustalW built into Bioedit (Thomson et al. 1994, Hall 1999) using the default parameters. The final sequence length used for the further phylogenetic analyses was $401 \mathrm{bp}$ aligned in MUSCLE (Edgar 2004). The phylogenetic analyses were performed using Bayesian inference method. The GTR $+\mathrm{G}$ substitution model was selected as the optimal nucleotide substitution and bootstrap value 1000 used as replications implemented in Mega v.6.06. (Tamura et al. 2013).

For Bayesian analysis, ten million generations were run (Markov chain Monte Carlo method) with a sampling frequency of 1000, as implemented in $\mathrm{Mr}$. Bayes v3.1.2. (Ronquist and Huelsenbeck 2003). Convergence of the runs was assessed by the average split frequency of standard deviations $(<0.01)$ and by 
checking the potential scale reduction factors $(\sim 1.0)$ for all model parameters. $30 \%$ of the trees were discarded as burn in and the remaining trees were used to generate the 50\% majority rule consensus tree and to estimate the Bayesian posterior probabilities. Genetic pairwise distance of all taxa was calculated using Kimura-2 parameter model in Mega v.6.06. (Tamura et al. 2013, Kimura 1980). The matrilineal genealogy was assumed to reflect the phylogenetic relationships of the species.

In the present trees a distinct Indian and Asian clade was retrieved with high support. The sequence divergences between Eutropis multifasciata and other congeneric species were significant, ranging from 0.1 to $13.6 \%$ for $16 \mathrm{~S}$ rRNA (Table 2). Intraspecific genetic divergence within E. multifasciata was estimated $10.3 \%$ (Thailand population). E. multifasciata formed a distinct clade in the phylogenetic analyses with high posterior probability support both in BI (100\%) and ML (98\%) (Fig. 2). Interestingly it clade with Indian Assam and Myanmar multifasciata species. An aligned figure was drawn with our mtDNA sequences with others Asian E. multifasciatus from different countries compared by MEGA was downloaded from GenBank (Fig. 3).

\section{RESULTS AND DISCUSSION}

The molecular data presented here demonstrate the monophyly of the Asian Eutropis multifasciata and further support the generic assignment of Asian population of this large genus to Eutropis. Bangladeshi Eutropis was nested within the Indian Eutropis clade as well as sister clade with other Asian multifasciata. For the phylogenetic relationship 31 mitochondrial 16S rRNA gene fragments were analyzed. The nucleotide sequences of $16 \mathrm{~S} \mathrm{rRNA}$ gene fragment are shown in Fig. 2. The total 16S rRNA gene fragment consists of 401 sites, 153 of which were variables. Phylogenetic tree with E. multifascita population from Asian countries based on 16S rRNA gene fragment is shown in Fig. 3.

In this phylogenetic tree, specimens from Asia are well supported as a distinct clade (G1) that include all specimens of E. multifasciata. The other major groups are from available species clade under the genus Eutropis (G2). In clade G1, present E. multifasciata sequences clade with Indian species, and the remaining South-East Asian multifasciata clade in a sister group having high support $(\mathrm{BI}=100 \%, \mathrm{ML}=98 \%)$. Although, Indonesian species has separate sister clade. Mausfeld et al. (2002) used mitochondrial 16S and 12S rRNA gene to study phylogenetic affinities of Mabuya reflect four independent origins as Southern American, Asian, Afro-Malagacy and Cape Verdean: Mabuya Fitzinger 1926, Eutropis Fitzinger 1843; Euprepis Wagner 1830 and Chioninia Gray 1945 


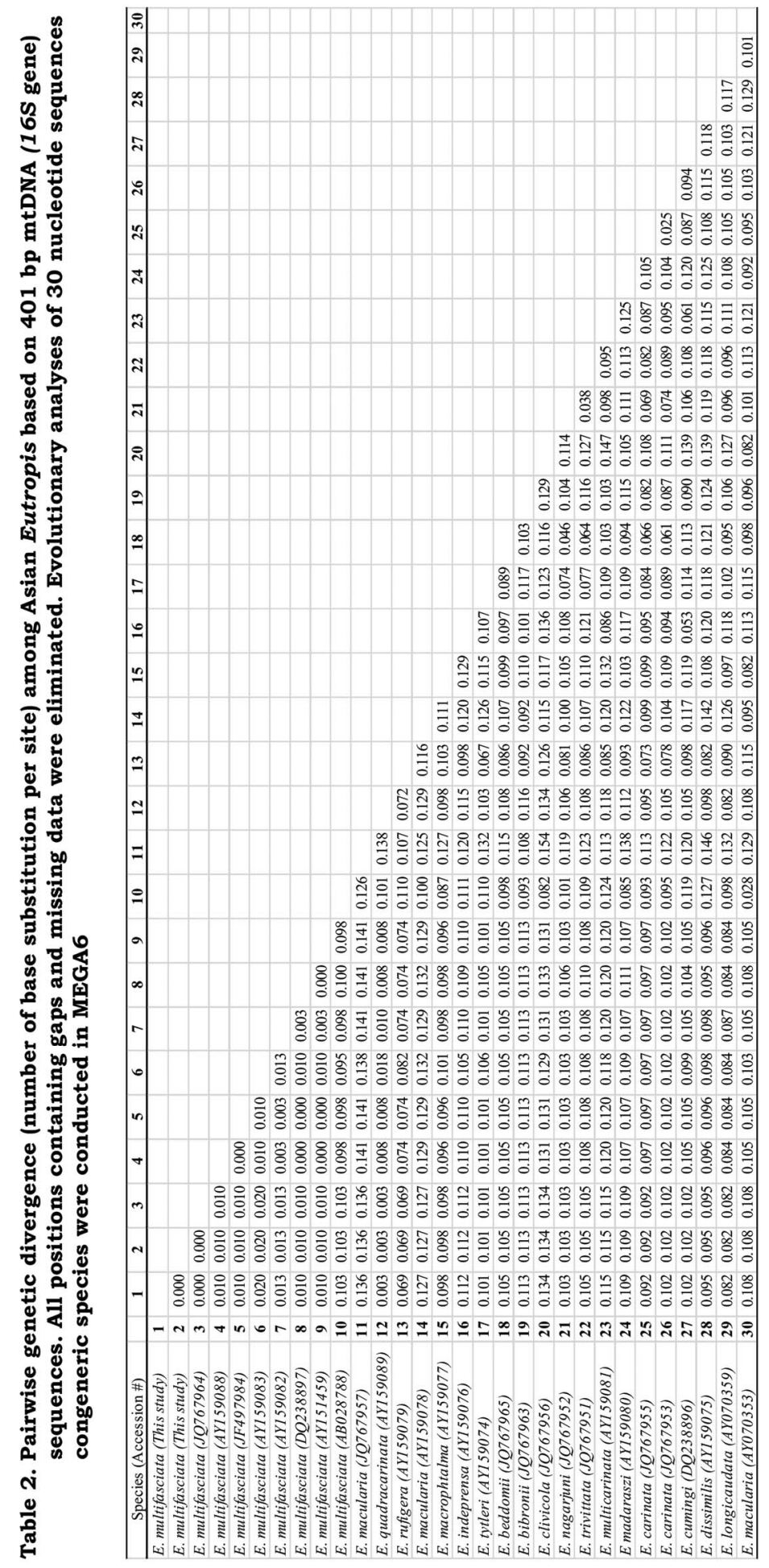




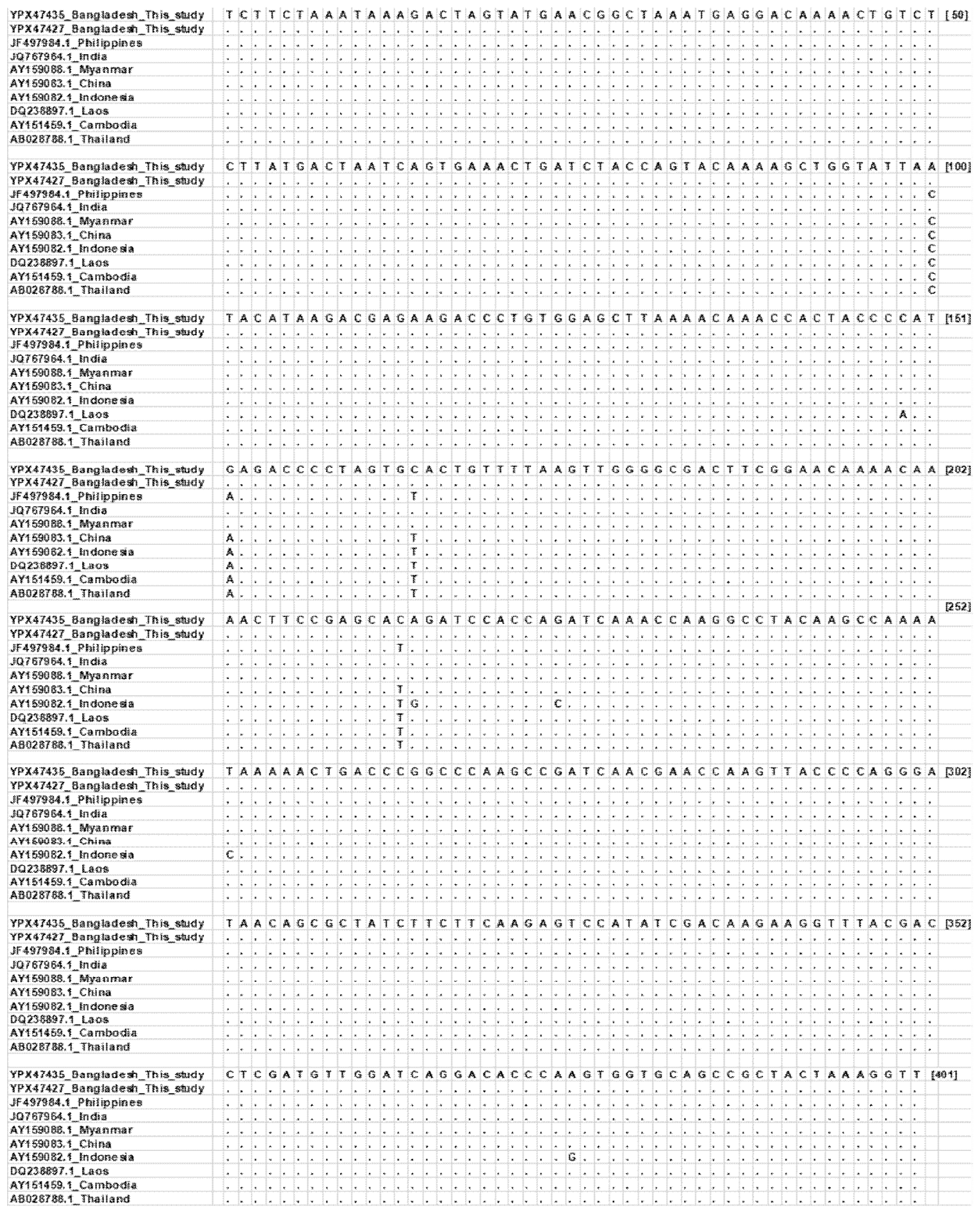

Fig. 3. Aligned sequences of $401 \mathrm{bp}$ segment of $16 \mathrm{~S}$ rRNA mitochondrial gene from the Asian Eutropis multifasciata population. Dots indicate identity to the Bangladeshi Eutropis multifasciata compared with other Asian countries.

clade four respectively (Mausfeld et al. 2002). However, in later, Mausfeld and Schmid (2003) again used 12S+16S rRNA mitochondrial genes combined used to 
resolve the previous problem, and found that all Asian Scincid lizard genus Eutropis clade in a monophyletic clade but the problem remains in $E$. multifasciata. To resolve this problem, they used seven E. multifasciata population from different geographic location and found that both BI and ML tree showed similar topology supporting monophyletic clade containing al South Asian Eutropis taxa.

Authors of this study also found the similar tree topology support that all South Asian E. multifasciata showed strong bootstrap support for monophyletic clade. However, South East Asian Eutropis clade two monophyletic subgroups are conspicuous; one containing Bangladesh and Indian E. multifasciata including Myanmar and other containing Indonesia, Philippines, China, Laos, Cambodia and Thailand population of E. multifasciata. In G2, several subgroups were formed; Myanmar Eutropis clade with Indian bibrinii, all Philippines Eutropis formed monophyletic clade (E. multicarinata + E. indreprensa $+E$. cumingi) in this study agree with previous studies (Crombie and Pregill 1999, Brown and Alcala 1980). Indian all main land species formed single clade ( $E$. carinata + beddomii + nagarjuni + trivittata $)$ with high support value $(\mathrm{BI}=99 \%)$, however Andaman island species formed sister clade. Other island species like Sri Lanka, Java, Andaman clade with Pakistani E. macularia species. Only E. longicaudata from Vietnam formed individual clade with low support, and most dispersible species E. dissimilis of Myanmar clade G2 (ML $=66 \%$ ), although previously it was identified as Mabuya novencarinata (Mausfeld and Schmitz 2003). In the second group, E. macularia which is widely distributed is endemic in India and Sri Lanka. E. macularia is distributed in most areas of Indian subcontinent as well as South East Asia, although it was shown paraphyletic with respect to E. tammanna (Ota et al. 2001, Mausfeld and Schmitz 2003, Mausfeld et al. 2000, Das et al. 2008).

In the present result, the E. macularia clade with Indian subcontinental Eutropis population of Myanmar and Pakistan that is similar with that of DuttaRoy et al. (2012). The extensively distributed E. multifasciata recorded from India in the west of Philippines in the northeast (Brown and Alcala 1980, Tikader and Sharma 1992), Indonesia (Mertens 1930, Mausfeld and Böhme 2002) and other South East Asian (China, Cambodia, Laos) - forms a well-supported monophyletic clade $(\mathrm{ML}=99 \%, \mathrm{BI}=100 \%)$. Thus, we concluded that all currently recognized multifasciata populations evidently evolve from one common ancestor. Biogeographically, Bangladesh is part of Oriental region, nested between Indo-Himalayan and Indo-Chinese sub-regions of the Orient (Nishat et al. 2002). In this regard, Mani (1974) suggested that the Assam region of Northeast India might have served a gateway through which Southeast Asian 
elements reached Indian peninsula. North of Assam, the Himalayan chain of mountains acted as a barrier and south was covered by sea, therefore Assam as a possible route of which facilitated the exchange of biota.

Thus, the present study completely supports the hypothesis of Mani (1974) that Bangladeshi population of E. multifasciata clade with Assam E. multifasciata although the great dispersal ability of E. multifasciata via humans has already been indicated for Taiwan (Ota et al. 1994) and the Philippines (Brown and Alcala 1970). Although researchers (Meijaard and Grove 2006, Sengupta et al. 2009, Chen et al. 2018) have reported that the mighty Brahmaputra river has long been recognized as a barrier of many species in India and Indo-China sub-regions (Dutta-Roy et al. 2012), in case of E. multifasciata dispersal in Bangladesh such scenario was not effective. A recent survey (IUCN 2015) reported that this species is confined in Northeastern part of Bangladesh (Near Assam in India), however this first time reporting on molecular phylogenetic relationship of Eutropis multifasciata collected from the North-western part of Bangladesh needs further extensive survey throughout the country.

\section{CONCLUSION}

The molecular phylogenetic results of this study support one monophyletic subgroup containing all specimens of $E$. multifasciata and all recently recognized E. multifasciata populations have evolved from one common ancestor including Bangladesh. Habitat degradation is likely the cause of decline, but the species can adapt to some degree of habitat disturbances and the species categorized least concern to IUCN list Bangladesh.

Acknowledgements: The authors are grateful for every support provided by the Chairman, Department of Zoology, University of Rajshahi for letting permission to field works. Thanks to Ketab Ali, Laboratory Assistant, and Sahadat Hossain, Milon Hossain MS students of the Department of Zoology for their enthusiastic field collections during this survey. They sincerely thank Bangladesh Forest Department as they issued permission letter for carry tissues to Kunming Institute of Zoology, China for molecular works in their lab. A thank must be given to Dr. Chen Jin Min for his BI tree analysis help.

\section{LITERATURE CITED}

BOSSUYT F. and MILINKOVITCH M.C. 2000. Convergent adaptive radiations in Madagascan and Asian ranid frogs reveal covariation between larval and adult traits. Proc. Natl. Acad. Sci. USA 97: 6585-6590.

BOULENGER G.A. 1887. Catalogue of the Lizards in the British Museum (Natural History). Volume III. Lacertidae, Gerrosauridae, Scincidae, Anelytropidae, Dibamidae, Chamaeleonidae. London. 
BROWN W.C. and ALCALA A.C. 1970. The zoogeography of the herpetofauna of the Philippine Islands, a fringing archipelago. Proc. Cal. Acad. Sci. 38: 105-130.

BROWN W.C. and ALCALA A.C.1980. Philippine lizards of the family Scincidae (with a description of a new species of Tropidophorus by James P. Bacon). Sill. Univ. Nat. Sci. Monogr. 2: 1-264.

CHEN J.M., POYARKOV Jr. N.A., SUWANNAPOOM C., LATHROP A., Wu Y.H., ZHOU W.W., YUAN Z.Y., JIN J.Q., CHEN H.M., LIU H.Q. , NGUYEN T.Q, NGUYEN S.G., DUONG T.V., ETO K., NISHIKAWA K., MATSUI M., ORLOV N.L., STUART B.L., BROWN R.M., ROWLEY J.J.L., MURPHY R.W., WANG Y.Y. and CHE J. 2018. Large-scale phylogenetic analyses provide insights into unrecognized diversity and historical biogeography of Asian leaf-litter frogs, genus Leptolalax (Anura: Megophryidae). Mol. Phyl. Evol. 124: 162-171.

CROMBIE R.I. and PREGILL G.K. 1999. A checklist of the herpetofauna of the Palau Islands (Republic of Belau), Oceania. Herpetol. Monogr. 13: 29-80.

DAS A. 2008. Diversity and distribution of herpetofauna and evaluation of conservation status in Barail Hill Range (including Barail Wildlife Sanctuary), Assam, northeast India. Final Report Aaranyak. Guwahati. pp. 94.

DAS I., SILVA A.D. and AUSTIN C.C. 2008. A new species of Eutropis (Squamata: Scincidae) from Sri Lanka. Zootaxa 1700: 35-52.

DATTA-ROY A., SINGH M., SRINIVASULU C. and KARANTH K.P. 2012. Phylogeny of the Asian Eutropis (Squamata: Scincidae) reveals an 'into India' endemic Indian radiation. Mol. Phyl. Evol. 63: $817-824$.

EDGAR R.C. 2004. MUSCLE: multiple sequence alignment with high accuracy and high throughput. Nucleic Acids Res. 32(5): 1792-1797.

FELSENSTEIN J. 2003. Confidence limits on phylogenies, an approach using bootstrap. Evolution 39: 783-791.

HALL T.A.1999. BioEdit: a user-friendly biological sequence alignment editor and analysis program for Windows95/98/NT. Nucleic Acids Symp. Ser. 41: 95-98.

IUCN Bangladesh. 2015. Red List of Bangladesh Volume 4: Reptiles and Amphibians. IUCN, International Union for Conservation of Nature, Bangladesh Country Office, Dhaka, Bangladesh, xvi+320 pp.

KHAN M.M.H. 2007. First report of Reeve's ground skink Scincella reevesi and Himalayan litter skink Sphenomorphus indicus from Bangladesh. Zoos' Print Journal 22(1): 2,545.

KIMURA M. 1980. A simple method for estimating evolutionary rate of base substitutions through comparative studies of nucleotide sequences. J. Mol. Evol. 16: 111-120.

MAHONY S.and REZA A.H.M.A. 2008. A herpetofauna collection from the Chittagong Hill Tracts, Bangladesh, with two new species records for the country. Hamadryad 32(1): 45-56.

MANI M.S. 1974. Biogeographical evolution in India. In: Mani, M.S. (Ed.), Ecology and Biogeography of India, Dr. W. Junk b.v. Publishers, The Hague, pp. 698-724.

MAUSFELD P. and BÖHME W. 2002. A new Mabuya from Java, Indonesia. Salamandra 38: 135144.

MAUSFELD P. and SCHMITZ A. 2003. Molecular phylogeography, intraspecific variation and speciation of the Asian scincid lizard genus Eutropis Fitzinger, 1843 (Squamata: Reptilia: Scincidae): taxonomic and biogeographic implications. Org. Div. Evol. 3: 161-171.

MAUSFELD P., SCHMITZ A., BÖHME W., MISOF B., VRCIBRADIC D. and ROCHA C.F.D. 2002. Phylogenetic affinities of Mabuya atlantica Schmidt, 1945, endemic to the Atlantic Ocean archipelago of Fernando de Noronha (Brazil): necessity of partitioning the genus Mabuya Fitzinger, 1826 (Scincidae: Lygosominae). Zool. Anz. 241: 281-293. 
MAUSFELD P., VENCES M., SCHMITZ A. and VEITH M. 2000. First data on the molecular phylogeography of scincid lizards of the genus Mabuya. Mol. Phyl. Evol. 17: 11-14.

MEIJAARD E. and GROVES C.P. 2006. The geography of mammals and rivers in mainland Southeast Asia, Springer Science + Business Media, LLC, 233 Spring Street, New York, NY 10013, USA, pp. 305-330 (Chapter 11).

MERTENS R.1930. Die Amphibien und Reptilien der Inseln Bali, Lombok, Sumbawa und Flores. Abh Senckenberg Naturf Gesell. 42: 115-344.

NISHAT A., HUQ S.M.I., BARUA S.P., REZA A.H.M.A. and KHAN A.S.M. 2002. Bio-ecological Zones of Bangladesh. IUCN, The World Conservation Union, Bangladesh Country Office. XII+ 141 pp.

OTA H., CHANG H.W., LIU K.C. and HIKIDA T. 1994. A new record of the viviparous skink, M Mertens, R. (1930): Die Amphibien und Reptilien der Inseln Bali, Lombok, Sumbawa und Flores. Abh. Senckenberg. Naturf. Gesell. 42: 115-344. Mabuya multifasciata (Kuhl, 1820) (Squamata: Reptilia), from Taiwan. Zool Studies 33: 86-8.

POSADA D. and CRANDALL K.A. 1998. Model test: Testing the model of DNA substitution. Bioinformatics 14: 817-818.

RONQUIST F. and HUELSENBECK J.P. 2003. MrBayes 3: Bayesian phylogenetic inference under mixed models. Bioinformatics 19: 1572-1574.

ROOIJ N.D. 1915. The reptiles of Indo-Australian Archipelago. E.J. Brill. Ltd. Leiden. pp. 364.

SENGUPTA S., DAS A., DAS S., HUSSAIN B., CHOUDHURY N.K. and DUTTA S.K. 2009. Taxonomy and biogeography of Kaloula species of eastern India. Nat. Hist. J. Chulalongkorn Univ. 9: 209-222.

SHARMA R.C. 2002. The fauna of India and the adjacent countries - Reptilia (Sauria). vol. II, Zoological Survey of India, Kolkata. pp. 1-430.

SMITH M.A. 1935. The Fauna of British India, Including Ceylon and Burma, Reptilia and Amphibia, vol. II - Sauria. Taylor and Francis, London.

STAMATAKIS A., HOOVER P., ROUGEMONT J. and RENNER S. 2008. A rapid bootstrap algorithm for the RAxML web servers. Syst. Biol. 57(5): 758-771.

SWOFFORD D.L. 2002. PAUP: Phylogenetic Analysis Using Parsimony (and Other Methods), Version 4.10b. Sinauer Associates, Sunderland, MA.

TAJIMA F. and NEI M. 1984. Estimation of evolutionary distance between nucleotide sequences. Mol. Bio. Evol. 1: 269-285.

TAMURA K., STECHER G., PETERSON D., FILIPSKI A. and KUMAR S. 2013. MEGA6: Molecular evolutionary genetics analysis version 6.0. Mol. Biol. Evol. 30: 2725-2729.

THOMPSON J.D., HIGGINS D.G. and GIBSON T.J. 1994. CLUSTAL W: Improving the sensitivity of progressive multiple sequence alignment through sequence weighting, position-specific gap penalties and weight matrix choice. Nucleic Acids Res. 22: 4673-4680.

TIKADER B.K. and SHARMA R.C. 1992. Hand book of Indian Lizards. The Radiant Process Private Ltd., Kolkata. xv+250 pp. 